\title{
Effects of Intramuscular Vitamin E Administration on Chemical Composition of Lactating West African Dwarf (Wad) Goats Milk.
}

\section{Samson Adeoye ( $\nabla$ adeolusambabs@yahoo.com )}

Federal University of Agriculture Abeokuta https://orcid.org/0000-0003-1498-4365

\section{Ikechukwu James}

Federal University of Agriculture, Abeokuta, Ogun State

\section{Emmanuela Nwosu}

Federal University of Agriculture Abeokuta

\section{James Daramola}

Federal University of Agriculture Abeokuta

0. 0 Adewumi

Federal University of Agriculture Abeokuta

\section{Akintayo Adelabu}

Federal University of Agriculture, Abeokuta

\section{Research Article}

Keywords: Lactating West African Dwarf Goats, Vitamin E, Milk constituents, Stage of lactation.

Posted Date: January 27th, 2022

DOI: https://doi.org/10.21203/rs.3.rs-1089187/v1

License: (c) (i) This work is licensed under a Creative Commons Attribution 4.0 International License. Read Full License 


\section{Abstract}

Goats in Africa are constantly exposed to adverse weather conditions which leads to production deficiencies. Vitamin $\mathrm{E}$ ameliorates such effects as it aids better utilization of nutrients and increases quality of animal-based products, especially milk. This study investigated effect of vitamin E administration on some milk constituents of lactating West Africa Dwarf (WAD) goats. Twenty-four (24) lactating WAD does were randomly assigned to three treatment groups: T0 (control) received no vitamin E, while lactating does in T2 and T3 received 75 and $150 \mathrm{IU}$ of vitamin E respectively. Milk samples were collected, frozen at $-4^{\circ} \mathrm{C}$ and analyzed for some milk constituents. Lactating does administered $150 \mathrm{IU}$ produced the highest (p\&lt;0.05) milk protein (3.66\%), titratable acidity $(0.20 \%)$, total solids $(13 \%)$ and casein $(3.52 \%)$, but higher mean value of calcium $(257.63 \mathrm{mg} / 100 \mathrm{~g})$ was recorded compared to does injected $75 \mathrm{IU}$. Late stage of lactation produced the highest (p\&lt;0.05) milk protein (3.88\%), lactose $(4.62 \%)$, total solids $(13.17 \%)$, solids-non-fat (9.41\%) and casein $(3.53 \%)$ while early stage of lactation had the highest (p\&lt;0.05) calcium $(266.21 \mathrm{mg} / 100 \mathrm{~g})$, phosphorus $(28.98$ $\mathrm{mg} / 100 \mathrm{~g})$, zinc $(2.68 \mathrm{mg} / 100 \mathrm{~g})$ and copper $(0.22 \mathrm{mg} / 100 \mathrm{~g})$. Milk protein, lactose (LAC), moisture content (MC), total solids (TS), solids-non-fat (SNF), casein and copper (Cu) were stable (p\&lt;0.05) at the end of twelve weeks of milk storage duration (MSD). The study concluded that vitamin E administration improved the quality of milk constituents of lactating WAD does.

\section{Introduction}

Goat milk can serve as an alternative for rural households when cow milk is limited (Greyling, et al., 2004). Most local goat farmers may not be able to afford to keep exotic goat breeds for the purpose of milk production because of limited finance and the expertise to manage them in communal areas (Maphosa, et al., 2009). Goats in Africa are constantly exposed to adverse weather conditions which lead to production deficiencies. The herds of goats in Nigeria are majorly composed of local breeds which are constantly exposed to adverse effects of weather conditions, this culminates to poor health and low production. The supplementation of vitamin $\mathrm{E}$ has been used to improve the physiological status, reproductive performance and productivity (meat and milk) of ruminants especially sheep and cattle (Donnem et al., 2015 and Vagni et al., 2011). Vitamin E is a free radical scavenger and also prevents lipid peroxidation thus, encouraging milk yield and reducing mastitis. The antioxidant property of vitamin E, supplied alone or together with Se, has been reported in dairy species on milk yield and quality (Politis, et al., 2004; Tufarelli and Laudadio, 2011). There is an increase in the milk production of cows supplemented with vitamin E during a short term, the reason is because of less udder infections (Chawla, and Kaur, 2004). A research carried out on dairy goats showed positive influence of vitamin E and Se administration on milk yield, fat and protein contents (Tufarelli and Laudadio, 2011). There is paucity information about the use of vitamin E in goats contrary to much recorded in dairy cow and sheep production (Liu et al., 2013). Vitamin E is often added to milk to increase its nutritive value where it has been reduced during handling procaedures (Slavica et al., 2012).). Hence, the aim of this study was to investigate the effect of vitamin E administration on milk chemical composition of lactating West African Dwarf (WAD) does.

\section{Materials And Methods}

\section{Experimental site}

The experiment was carried out at the small-holder dairy goat research farm, in the Teaching and Research Unit of the Directorate of University Farms (DUFARMS), in the Federal University of Agriculture, Abeokuta, Ogun state, Nigeria. The research location falls within rain forest vegetation zone of the South-west, Nigeria, on latitude $7013^{\prime} 49.46$ " $\mathrm{N}$, longitude of $3026^{\prime} 11.98 " E$ and altitude 76 meters above sea level (Google Earth, 2016). The climate is humid with an annual rainfall of $1037 \mathrm{~mm}$, temperature at $34.7 \mathrm{OC}$ and humidity at $82 \%$ (Ufoegbune and Fabiyi, 2016). Laboratory analyses were carried out at the Animal Physiology and Central laboratories of the Federal University of Agriculture, Abeokuta. 
Twenty-four lactating WAD does with ages ranging from one to three years were selected randomly for the study from existing flock. The goats were managed semi-intensively and were fed $0.5 \mathrm{~g}$ concentrated feed per head per day with provision of clean water ad libitum. They were allowed to graze Panicum maximum field from 10 am to $2 \mathrm{pm}$. The proximate composition of the formulated feed is shown in Table 1. The experimental station was kept clean and biosecurity protocols were observed such as adequate quarantine of new animals, proper medication and careful observation on the animals was done daily to prevent outbreak of disease.

Experimental design and procedure

The twenty-four lactating (WAD) does were randomly assigned into three treatment groups of eight does each. The first group, the control (T0) received no vitamin E injection while the remaining two groups (T1 and T2) received 75 and $150 \mathrm{IU}$ of vitamin E injection respectively. The vitamin E (Tocopheryl acetate) manufactured by LABORATE Pharmaceuticals India Limited, Paonta Sahib, India, was used and administered intramuscularly to the lactating does immediately after parturition and subsequently on weekly basis for a period of twelve weeks. Milk collection was done 12 hours after separation from their kids. The kids were separated from their dams in the evening preceding the milking day between the hours of 7.00 and $8.00 \mathrm{pm}$ and transferred into artificial kid rearing unit. The milk sampling was done by hand milking (Millogo et al., 2012) from the lactating WAD does five days after injecting vitamin E, this was to ensure proper metabolism in the doe's system (Dersjant-Li and Peisker, 2010 and Hoppe, 2010). The milk samples collected every week were taken to laboratory and stored at $-40 \mathrm{C}$ until used for milk composition determination.

Determination of milk composition of lactating West African Dwarf goats

Milk protein was determined by Aldehyde method as described by Pyne (1932), Casein was gotten by burette reading (obtained from protein determination) multiplied by 1.38 as reported by Alganesh et al., (2007) and fat by Babcock method as reported by Herreid (2003). Ash content was determined by dividing weight of dried milk by weight of fresh sample of milk, and multiply all by 100 . The solids-not-fat (SNF) of milk was determined by direct oven drying of milk sample minus ether extraction as described by Clark et al.(1989). Thus percentage values of protein plus ash was subtracted from percentage SNF to obtain percentage lactose (LAC) as described by Economides (1986). Total solid (TS) of milk samples was determined by direct oven drying method as described by Clark et al. (1989), while moisture content (MC) was determined by subtraction of percentage total solid (TS) from 100 (AOAC,1993). Titratable acidity (TA) is equal to 0.009 multiplied by the product of volume of $\mathrm{N} / \mathrm{NaOH}$ used and 100 weight of milk samples (AOAC,1990). The milk minerals were determined through Atomic Absorption Spectrophotometry (AAS) machine (LCD, 1.5nm, 100-1100nm, Vimal Enterprises, Mumbai, India) as described by Al-Wabel (2008).

Statistical design

Data were analysed using the general linear model procedure in the Statistical Analysis System software package version 9.2 (SAS, 2001) to determine the effect of vitamin E, stage of lactation and storage duration on chemical composition of WAD milk. . Significant differences between the means for vitamin levels, stage of lactation and storage duration were performed using the Duncan's multiple range test procedure of SAS, with a significance level of $p<0.05$.

The statistical model used was:

$$
Y i j k l=\mu+A i+B j+C k+A^{\star} B i j+A^{\star} C i k+B^{\star} C j k+\bigotimes i j k l
$$

WhereYijkl = Traits of interest (milk protein, casein, fat, LAC, TA, TS, SNF, MC, \& ash)

$\mu=$ Population mean 
$A i=$ Fixed effect of ith vitamin $E$ administration $(j=0,75$, or $150 \mathrm{IU})$

$B j=$ Fixed effect of $j$ th stage of lactation $(i=1,2$, or 3$)$

$\mathrm{Ck}=$ Fixed effect of $\mathrm{kth}$ milk storage duration $(\mathrm{k}=0,1 \ldots \ldots . .12$ th $w \mathrm{k})$

$A{ }^{*} \mathrm{Bij}=$ The interaction between ith vitamin $\mathrm{E}$ dose and jth stage of lactation

$A^{*} \mathrm{Cik}=$ The interaction between ith vitamin $\mathrm{E}$ dose and kth milk storage duration

$\mathrm{B}^{\star} \mathrm{Cik}=$ The interaction between $\mathrm{jth}$ stage of lactation and kth milk storage duration

\ijkl = Random residual error

\section{Results}

The average chemical composition of milk from WAD goat for the levels of vitamin E administrated is presented in Table 2. The levels of vitamin $E$ administration on lactating does significantly $(P<0.05)$ influenced milk protein, lactose, titratable acidity (TA), moisture content (MC), total solids (TS) and casein, but milk fat, solids-not-fat (SNF) and ash were not significantly $(P>0.05)$ affected. The mean values of milk protein, TA, TS and casein increased consistently with increase in the levels of vitamin E administration but reverse was the case for milk lactose and MC. The highest protein, total solid and casein contents were obtained when $150 \mathrm{IU}$ of vitamin E was administered and the values were (3.66 \%), $(13.00 \%)$ and $(3.52 \%)$ respectively.

From Table 2, the chemical composition of the milk protein, lactose, MC, TS, SNF and casein were significantly $(P<0.05)$ influenced by stage of lactation but milk fat, TA and ash were not affected. The means of milk protein, TS, SNF and casein increased consistently as stage of lactation advanced while those of MC decreased consistently. The means of milk lactose however increased inconsistently as stage of lactation advanced. Highest means of milk protein (3.88 \%), TS $(13.17 \%)$, SNF (9.41\%) and casein (3.53 \%) were recorded at late stage of lactation.

The means chemical composition of milk protein, fat, TS and casein decreased inconsistently as milk storage duration (MSD) advanced, while, those of milk lactose, MC and SNF increased inconsistently Table 2. Among the chemical composition observed, only mean of milk fat were not stable during MSD, the mean values decreased from $5.20 \%$ at the first week to $3.25 \%$ at the twelfth week of MSD.

The means of calcium $(\mathrm{Ca})$ and phosphorus $(P)$ were significantly $(P<0.05)$ influenced by the levels of vitamin $E$ administration but sodium $(\mathrm{Na})$, zinc $(\mathrm{Zn})$ and copper $(\mathrm{Cu})$ were not significantly $(P>0.05)$ affected Table 3. Lactating does which received no vitamin $E$ (control group) had the highest Ca $(275.53 \mathrm{mg} / 100 \mathrm{~g})$ and $\mathrm{P}(30.22 \mathrm{mg} / 100 \mathrm{~g})$ compared to does which received 75 and $150 \mathrm{IU}$. The means of calcium in milk decreased inconsistently from 0 IU to $150 \mathrm{IU}$ while phosphorus decreased consistently. The $\mathrm{Ca}, \mathrm{P}, \mathrm{Zn}$ and $\mathrm{Cu}$ content of milk were significantly $(\mathrm{P}<0.05)$ influenced by stage of lactation Table 3. The highest means of Ca (266.21mg/100g), P (28.98mg/100g), Zn (2.68mg/100g) and Cu $(0.22 \mathrm{mg} / 100 \mathrm{~g})$ were obtained at early stage of lactation. The means decreased consistently till late stage of lactation. Storage duration significantly $(P<0.05)$ affected copper content of milk of lactating (WAD) does was. The means of the copper content increased inconsistently with the highest mean $(0.25 \mathrm{mg} / 100 \mathrm{~g})$ at twelfth week. Other minerals (Ca, $\mathrm{P}, \mathrm{Na}$, and $\mathrm{Zn}$ ) were not significantly $(\mathrm{P}>0.05)$ influenced by the storage duration but were available and stable.

\section{Discussion}

Administration of vitamin E increased milk protein, fat, TA, TS and casein and this could be attributed to the role of vitamin $E$ at enhancing nutrient metabolism and utilization in animals. The result of this study is in line with the findings 
of Keikha et al. (2021) who reported that supplementation of maternal diet with (vitamin E) resulted in increased milk constituent because vitamin E encourages nutrient metabolism. Similar result was reported of vitamin E by Al-Musodi and Jaafar, (2019) using lactating Iraqi goats. The decline observed in the milk lactose and MC of the lactating WAD does as the level of vitamin $\mathrm{E}$ administration increased could be due to ameliorative activities of vitamin $\mathrm{E}$. The formation of nutrients in the body of an animal is energy sapping and may involve production of excessive oxidants. Vitamin $\mathrm{E}$ could have made use of lactose (energy source) and moisture content (soluble medium) to reduce the oxidants. This observation is in line with the report of (Carrigan et al., 2010); Slavica et al., 2012); Manish et al., 2016Andrew-Weil, 2018). It was reported by Carrigan et al. (2010) that higher volume of vitamin E administration led to hydrolysis of lactose (a disaccharide) in mammalian milk to a good quality low-lactose milk.

Stage of lactation increased milk protein, LAC, TS, SNF and casein of lactating WAD does and this could be as a result of increase in the influx of nutrient supplied by the blood to the mammary gland. This result is in agreement with the findings of (Ahamefule, et al.,2012 and Oyekoya, 2017) in WAD goats and in other breeds like the Polish White improved goats (Olechnowicz and Sobek, 2008), Najdi ewes (Ayadi et al., 2014) and Baladi goats (El-Tarabany et al., 2018). The decrease in the milk MC as the stage of lactation increased in this current study is in accordance with the result reported by Pollott and Gootwine, (2000).

There was stability in the means of milk protein, LAC, MC, TS, SNF and casein throughout storage duration (MSD) and it is in line with the findings of Ahrabi et al. (2016) who reported that macronutrients remained unchanged (stable), when frozen for nine months at $-20^{\circ} \mathrm{C}$. Larger percentage of mean of milk protein obtained in this study falls within the range 2.90-4.60\% and 3.17-5.45\% obtained by Haenlein (1980) in Delware goats and Tona et al. (2017) in WAD goats respectively. The mean of milk protein (3.38\%) at the end of milk storage duration (MSD) was higher than the protein content reported by several authors with fresh goat milk: 3.20\% (USA), 2.90\% (Ethiopia), 3.20\% (Brazil), 3.07\% (Nigeria) and 3.32\% (Egypt) by Penn State Extension (2017), Getaneh et al. (2016), Yadav et al. (2016), Mba et al. (1975) and Soliman (2005) respectively. The observation from this current study is in line with that of Iqbal (2016) who said that the temperature on different types of storage (room, refrigerator and freezing) did not affect the levels of protein. The milk protein at the end of MSD in this current study differed from the report of Devendra and McLeroy, (1996) who reported $3.70 \%$ protein content in fresh goat milk analyzed. The mean of milk lactose (4.62 \%) at the end of MSD is in line with the range (3.80-5.10\%) reported by Haenlein (1980). It was also found to be higher than the recommended values: $4.20 \%$ reported by the European Union Quality standard for unprocessed whole milk (Alganesh, 2016) and above 4.27\%, 4.60\%, 4.08\%, 4.09\% and 4.10\% reported by Kumar et al. (2012), Yadav et al. (2016), Getaneh et al. (2016), El-Tarabany et al. (2016) and Penn State Extension (2017) respectively from different fresh goat milk. The reduction in the means of milk fat (5.20 to $3.25 \mathrm{mg} / 100 \mathrm{~g})$ as MSD advanced could be as a result of exposure of milk fat globule membranes to lipolytic bacteria and breakage of binding sites of ions such as calcium and other milk components. This observation is in line with the report of Neville et al. (1994) and lqbal et al. (2016) who reported that MSD significantly influence fat content. This report corroborated the findings of Jensen (1989) who reported that reduction in milk fat could be as a result of breakage of emulsion between the milk fat globules and the other milk components which must have led to lipid adhering to the sides of the container during freezing. The means of milk fat at the end of MSD (3.25\%) falls within the range of fresh milk fat (3.00-5.50\%) reported by Haenlein (1980) in Saanen goats. The stability in milk MC, TS, SNF and casein through the MSD maintenance of milk structure brought about by the uninterrupted storage temperature $\left(-4^{\circ} \mathrm{C}\right)$. This observation is in line with the reports of Haenlein (1980) and Claeys et al. (2014), who reported that milk constituents were relatively stable and falls within the normal range throughout storage duration.

The significant decrease in the mean of milk calcium $(\mathrm{Ca})$ and phosphorous $(\mathrm{P})$ obtained after vitamin $\mathrm{E}$ administration is in accordance with the work of Murphy et al. (1980) who reported that higher levels of vitamin E supplementation reduced calcium and phosphorus in blood plasma, dry fat-free bone and bone ash in chicks. The calcium content of milk recorded $(275.53,183.57$ and $257.63 \mathrm{mg} / 100 \mathrm{~g})$ in this current study, agreed with the range $(86-1113 \mathrm{mg} / 100 \mathrm{~g})$ reported

Page 5/14 
by Gajewska et al. (1997). However, the calcium in the milk recorded, is against the range 134.00-155.10, 120.63-132.57 and $130.28 \mathrm{mg} / 100 \mathrm{~g}$ reported by (Alichanidis and Polychroniadou,1996); Recommended Daily AllowancesRDAs,2002and Soliman,2005) respectively. The phosphorous in the milk followed a similar trend like calcium and it was in line with the report of WHO / FAO (1996).

There were consistent decrease in means of milk $\mathrm{Ca}, \mathrm{P}, \mathrm{Zn}$ and $\mathrm{Cu}$ as stage of lactation advanced and this could be due to normal phenomenon in milk yield of goats which determines the milk components qualities (Getaneh et al., 2016) The result of this study agreed with the report of (Mahmoud et al., 2014) who stated that as lactation progresses, the milk constituents decreased. The observation from this current study is comparable with the findings of Schmidely et al. (2002) in Alpine and Saanen dairy goats who recorded the same trend for Ca and P during lactation period. The report of (Aganga et al., 2002; Assan, 2014) however disagrees with the observation of this current study, they reported that minerals fluctuated throughout the lactation period in Tshwana goat. The mean of Cu component of the milk was inconsistent through the MSD and could be attributed to change and re-distribution of the trace element among its binding compounds which potentially affect its bioavailability. The mean of copper $(0.25 \mathrm{mg} / 100 \mathrm{gm})$ recorded at the end of MSD in this current study exceeds that $(0.07 \mathrm{mg} / 100 \mathrm{gm})$ reported by Sawaya et al. (1984) from fresh milk of Aardi and Masri goats of Saudi Arabia. The value was however lower to that (0.28 mg / L) reported by Akinsoyinu et al. (1979) from fresh milk of WAD goats.

\section{Conclusion}

Administration of vitamin $E$ in this study improved the quality and stability of milk chemical compositions of lactating West African Dwarf does. Vitamin E can therefore be a beneficial supplement in milk production of goats in the tropical environment. Further studies are recommended with higher doses.

\section{Declarations}

\section{Author contribution:}

Conceptualization, methodology, supervision, writing and review of the original draft: Samson Olubode Babalola Adeoye, Ikechukwu Joseph James.

Data collection, formal analysis, writing, and review: Samson Olubode Babalola Adeoye, Akintayo Olumide Adelabu, Emmanuela Uchenna Nwosu.

Project supervision, review, and editing: Ikechukwu Joseph James, James Olamitibo Daramola. and Olajumoke Olusola Adewumi

All authors read and approved the final manuscript.

\section{Data availability:}

The datasets generated during and/or analysed during the current study are available from the corresponding author on reasonable request.

Code availability: Not applicable.

\section{Declarations}

Statement of animal right: The research was conducted in accordance with applicable international, national and institutional guidelines for the care and use of animals. 


\section{Conflict of interest}

The authors declare no competing interests

\section{Financial Statements}

No funds, grants, or other support was received.

\section{References}

1. Aganga, A. A., Amarteifo, J. O., Nkile, N.,2002. Stage of lactation on nutrient composition of Tswana sheep and goat milk. Journal of Food Composition Analyses 15(5):533-543.

2. Ahamefule, F.O., Odilinye, O., Nwachukwu, E. N., 2012. Milk yield and composition of Red Sokoto and West African Dwarf Does raised intensively in a hot humid environment. Iranian Journal of Applied Animal Science 2 (2): 143-149.

3. Ahrabi, A., Handa, D., Codipilly, C. N., Potak, D., Aharon, G.G., Schanler, R. J., 2016. Effects of Extended Freezer Storage on the Integrity of Human Milk. Journal of Pediatrics177:140-143.

4. Akinsoyinu, A. O., Tewe, O.O., Mba, A. U., 1979. Concentration of trace elements in milk of West African Dwarf Goats affected by state of lactation. Journal of Dairy science. 62(6):921-924.

5. Alganesh, T., Ofodile, L.N., Fekadu, B., 2007. Microbial Quality and Chemical Composition of Raw Whole Milk from Horro Cattle in East Wollega, Ethiopia. Ethiopia Journal of Education and Sciences 3(1):1-10.

6. Alganesh, T. G., 2016. Assessment of Safety and Quality of Raw Whole Cow Milk Produced and Marketed by Smallholders in Central Highlands of Ethiopia. Food Science and Quality Management, www.iiste.org 49:63-71.

7. Alichanidis, E., Polychroniadou, A., 1996. Special features of dairy products from ewe and goat milk from the physicochemical and organoleptic point of view. In: Proceedings, Production and Utilization of Ewe and Goat Milk, Crete, Greece, International Dairy Federation Publication Brussels pp 21-43.

8. Al-Musodi M.F., Jaafar, H. M., 2019. Effect of dietary Zingiber officinals root powder and vitamin E-selenium on milk yield and its chemical composition in lactating Iraqi female goats. IOP Conference Series: Earth and Environmental Science. International Conference on Agricultural Science 388:012-022.

9. Al-Wabel, N. A., 2008. Mineral content of Cattle, Camels, Goats and Sheep in the Central Region of Saudi Arabia. Asian Journal of Biochemistry 3:373-375.

10. Andrew-weil, M. D., 2018. Health Benefits of Pumpkin Seeds: Antioxidant rich, https://www.drweil.com, accessed: $7^{\text {th }}$ November, 2018.

11. Association of Official Analytical Chemists (AOAC). 1990. Official Methods of Analysis Chemists, 15th ed. AOAC, USA, Virginia, Arlington.

12. Association of Official Analytical Chemists (AOAC). 1993. Methods and determination of moisture. The AOAC Referee.17,pp 5-9

13. Assan. N., 2014. Influence of stage of lactation on quantitative and qualitative milk production parameters in goats. Scientific Journal of Animal Science 3(12):291-300.

14. Ayadi, M., Matar, A. M., Aljumaah, R. S., Alshaikh, M. A., Abouheif, M., 2014. Factors Affecting Milk Yeild, Composition and Udder Health of Najdi Ewes. International Journal of Veterinary Advances 6:28-33.

15. Carrigan, D., Curran, E., Keehan, D., White, R., 2010. A reduced lactose milk product and a process for the preparation thereof. A Glanbia Nutritionals Ireland Limited.https://patents.google.com/patent/W02010119439A1/en, accessed: $28^{\text {th }}$ February, 2020.

16. Claeys, L.W., Varraes, C., Cardoen, S., De Block, J., Huyghebaert, A., Raes, K., Dewettinck, K., 
17. Chawla, R., Kaur, H., 2004. Plasma antioxidant vitamin status of periparturient cows supplemented with a-tocopherol and $\beta$-carotene. Animal Feed Science Technology 114: 438 279-285.

18. Clark, J. L., Barbano, D. M., Dunham, C. E., 1989. Direct oven drying method for determination of total solids content of milk and (direct oven-ether extraction) method for determination of solid-not-fat content of milk. Journal of Association of Analytical Chemist.72: 712-718.

19. Devendra, C., McLeroy, G. B., 1996. Goat and Sheep Production in the Tropics. 7th edition, Payne, W.J.A and Longman (ed.), London and New York Publishers pp1-55.

20. Dønnem, I., Randby, A.T., Hektoen, L., Avdem, F., Meling, S., Vage, A.O. Adnøy, T., Steinheim, G., Waage, S., 2015. Effect of Vitamin E Supplementation to Ewes in Late Pregnancy on the Rate of Stillborn Lambs. Small Ruminant Research 125:154-162.

21. Economides, S., 1986. Comparative studies of sheep and goats: milk yield and composition and growth rate of lambs and kids. Journal of Agricultural Science. 106, 477-484.

22. El-Tarabany, M. S.; El-Tarabany, A. A., Roushdy, E. M., 2016. Impact of lactation stage on milk composition and blood biochemical and haematological parameters of dairy Baladi goats. Saudi Journal of Biological Science, http://dx.doi.org/10.1016/j. $\underline{\text { sjbs. }}$.

23. El-Tarabany, M, S., Akram, A, E., Roushdy, E, M., 2018. Impact of Lactation Stage on milk Composition and Blood Biochemical and Hematology Parameters of Dairy Baladi goats. Saudi Journal of Biological Sciences 25(8):16321638.

24. Gajewska, R, Ganowiak, Z., Nabrzyski, M., 1997. Composition of Nutrients and Minerals in some Goat Milk Products. Roczniki Panstwowego Zakladu Higieny 48 (4):409-414.

25. Getaneh, G., Mebrat, A., Wubie, A., Kendie, H., 2016. Review on Goat Milk Composition and Its Nutritive Value. Journal of Nutritional Health Science 3(4):401

26. GoogleEarth. 2016. Google earth version 7.1.5.1557. Digital globe http://www.earth.google.com.

27. Greyling, J.P.C.; Mmbengwa, V.M.; Schwalbach, L.M.J.; Muller, T., 2004. Comparative milk production potential of indigenous and Boer goats under two feeding systems in South Africa. Small Ruminant Research. 55, 97-105.

28. Haenlein, G.F.W., 1980. Mineral nutrition of goats. Journal of Dairy Science 63:1729-1748.

29. Herreid, E. O., 2003. The Babcock Test. A Review of the Literature. Journal of Dairy Science 25(4):324-343.

30. Iqbal, M., Lestari-Lily, A., Kurdanti, W., Mardiyati, N., 2016. Effect of temperature and storage duration on lactose, protein and fat content of breast milk. International Conference on Health and well-being (ICHNB) pp289-295.

31. Jensen, R. G., 1989. The Lipids of Human Milk. CRC Press, Boca Raton, Florida.

32. Keikha, M., Shayan-Moghadam, R., Bahreynian, M., Kelishadi, R., 2021. Nutritional Supplements and Mother's milk Composition: a systemic review of interventional studies. International Breastfeeding Journal 16(1):2021

33. Kumar S., Kumar, B., Kumar, R., Kumar, S., Khatkar, S., Kanawjia, S. K., 2012. Nurtional Features of Goat Milk. A Review. Indian Journal of Dairy Science 65(4)

34. Liu, K., Ge, S., Luo, H., Yue, D., Yan, L., 2013. Effects of Dietary Vitamin E on Muscle Vitamin E and Fatty Acid Content in Aohan Fine-Wool Sheep. Journal Animal Science and Biotechnology 4:21.

35. Mahmoud, N. M. A., El Zubeir, I. E. M., Fadlelmoula, A. A., 2014. Effect of Stage of Lactation on Milk Yield and Composition of First Kidder Damascus does in the Sudan. Journal of Animal Production Advances 4(3): $355-362$.

36. Manish, K., Rajesh, J., Shashi, N., 2016. Influence of Antioxidant Supplementation on Reproductive Performance of Summer Stressed Beetal Goats. Indian Veterinary Journal 93(9): 27-30.

37. Maphosa, V.; Sikosana, J.L.N.; Muchenje, V. Effect of doe milking and supplementation using Dichrostachys cinerea pods on kids and doe performance in grazing goats during the dry season. Tropical Animal Health and Production $2009,41,535-541$. 
38. Mba, A. V., Boya, B. S., Oyenuga, V. A., 1975. Studies on the Milk Composition of West Africa Dwarf, Red Sokoto and Saanen goats in Different Stages of Lactation. Journal of Dairy Research 42:217.

39. Murphy, T. P., Wright, K. E. and Pudelkiewicz. W. J., 1980. An Apparent Rachitogenic Effect of Excessive Vitamin E Intakes in the Chick. Department of Nutritional Sciences, University of Connecticut, Storrs, Connecticut 06268.

40. Neville, M. C., Keller, R. P. Casey, C., Allen, J. C., 1994. Calcium Partitioning in Human and Bovine Milk. Journal of Dairy Science 77:1964-1975.

41. Olechnowicz, J., Sobek, Z., 2008. Factors of Variation Influencing Production Level, SCC and basic milk composition in dairy goats. Journal of Animal Feed Science 17:41-49.

42. Oyekoya, A, A., 2017. Effect of Milking Interval on Milk Yield and Composition of West African Dwarf Goats. A Dissertation in the Requirement of the Award of Degree of Master. Department of Reproductive Physiology, Federal University of Agriculture, Abeokuta, Nigeria.

43. Penn State Extension, 2017. Dairy Goat Production. The Pennsylvania State University Extention Office, 323 Agricultural Administration Building, University Park, PA, 16802.

44. Politis, I., Bizelis, I., Tsiaras, A., Baldi, A., 2004 Effect of vitamin E supplementation on neutrophil function, milk composition and plasmin activity in dairy cows in a commercial herd. Journal of Dairy Research 71: $273-278$.

45. Pollot, G.E. and Gootwine, E. 2000. Appropriate Mathematical Model for Describing the Complete Lactation of Dairy Sheep. Animal Science 71:197-207.

46. Pyne, G. T., 1932. The determination of milk-protein by formaldehyde titration: National Centre for Biotechnology Information, USA. National Library of Medicine 8600 Rockville Pike, Bethesda MD, 20894 USA. Journal of Biochemistry. 26: 1006-1014.

47. Recommended Dietary Allowances (RDAs). 2002. Recommended Intakes for Individuals. Macronutrients, Elements. Food and Nutrition Board, Institute of Medicine, National Academies

48. SAS., 2001. User's Guide Statistical Analysis System, SAS (r) proprietary software 9.2 (TS1MO), SAS Version 9.1, Institute Incorporation, Cary, NC, USA.

49. Sawaya, W, N., Khali, J.K., Al-Shalhat, A.F., 1984. Mineral and Vitamin Content of goat's milk. Journal of America Diet Association, 84 (4):433-435.

50. Schmidely. P., Meschy, F., Tessier, J., Sauvant, D., 2002. Lactation Response and Nitrogen, Calcium, and Phosphorus Utilization of Dairy Goats Differing by the Genotype for $a_{\mathrm{S} 1}$-Casein in Milk, and Fed Diets Varying in Crude Protein Concentration. Journal of Dairy Science 85(9):2299-2307.

51. Slavica, S., Jelena, Z., Radmila, P., Gordana, K., Natasa, T., Slavoljub, Z., 2012. Assessment of a-tocopherol Content in Cow and Goat Milk. The Serbian Market Scientific Paper 637(497):543-645.

52. Soliman, G. Z. A., 2005. Comparison of Chemical and Mineral Content Of Milk from Human, Cow, Buffalo, Camel and Goat in Egypt. The Egyptian Journal of Hospital Medicine 21:116-130.

53. Tona, O. G., Adewumi, O, O., Theophilus, S. S., 2017. Milk Yield (Offtake), Composition and Microbiological Quality in West African Dwarf Goats Fed Concentrate Diets with Varying Levels of Moringa Oleifera Leafmeal and Seedmeals. Journal of Biology Agriculture and Healthcare 7(14): 2224-3208.

54. Tufarelli, V., Laudadio, V., 2011. Dietary Supplementation with Selenium and Vitamin E Improves Milk Yield, Composition and Rheological Properties of Dairy Jonica Goats. Journal of Dairy Research, 78(2):144-148.

55. Ufoegbune, G.C., Fabiyi, S., 2016. Identification of Land Areas Suitable for Fadama Farming at Federal University of Agriculture, Abeokuta, Nigeria, using GIS. Department of Water Resources and Agrometrology, Federal University of Agriculture, Abeokuta. Journal of Applied Science and Environmental Management 20(4):1027-1032.

56. Vagni, S., Saccone, F., Pinotti, L., Baldi, A., 2011. Vitamin E Bioavailability: Past and Present Insights. Food and Nutrition Sciences 2(10):1088-1096. 
57. World Health Organization / Food and Agricultural Organization (WHO/FAO). 1996. Trace elements in Human nutrition and health.

58. Yadav, A.K., Singh, J., Yadav, S.K., 2016. Composition, Nutritional and Therapeutic Values of goat milk: A review. Asian Journal of Dairy and Food Research 35(2):96-102

\section{Tables}

Table 1. Percentage composition of concentrate feed offered West African Dwarf goats

\begin{tabular}{|ll|}
\hline Feed Ingredients & $(\%)$ \\
\hline Corn bran & 17 \\
\hline Rice bran & 18 \\
\hline Palm kernel cake & 24 \\
\hline Brewers dried grain & 28 \\
\hline Groundnut cake & 10 \\
\hline Bone meal & 1 \\
\hline Limestone & 1 \\
\hline Salt & 0.5 \\
\hline Corn bran & 0.5 \\
\hline Total & 100 \\
\hline Calculated Analyses & \\
\hline Crude Protein (\%) & 17.89 \\
\hline Crude Fibre (\%) & 13.27 \\
\hline Ether Extracts (\%) & 6.45 \\
\hline D.E (MJ/Kg) & 2.2802 \\
\hline
\end{tabular}

Table 2. Least squares means showing effect of vitamin E administration, stage of lactation and storage duration on milk composition of lactating WAD does

a, b, c Means in the same column having different superscripts differ significantly (Pख0.05). N=Number of observations, TA=Titratable acidity, MC= Moisture content, TS=Total solid and SNF=Solids-non-fat

Table 3: Least squares means showing effect of vitamin E administration, stage of lactation and storage duration on some milk minerals of lactating WAD does

a, b, c Means in the same column having different superscripts differ significantly (Pख0.05). N=Number of observations 


\begin{tabular}{|c|c|c|c|c|c|c|c|c|c|c|}
\hline Factors & $\mathrm{N}$ & Protein & actose & Fat & TA & $\mathrm{MC}$ & TS & SNF & Casein & Ash \\
\hline \multicolumn{11}{|l|}{$\begin{array}{l}\text { Vitamin } \\
\mathrm{E}\end{array}$} \\
\hline $0 \mathrm{IU}$ & 36 & $\begin{array}{l}3.32 \pm \\
0.14^{b}\end{array}$ & $\begin{array}{l}4.64 \pm \\
0.05^{a}\end{array}$ & $\begin{array}{l}3.74 \pm \\
0.11\end{array}$ & $\begin{array}{l}0.18 \pm \\
0.01^{b}\end{array}$ & $\begin{array}{l}87.45 \pm \\
0.16^{a}\end{array}$ & $\begin{array}{l}12.55 \\
\pm \\
0.16^{b}\end{array}$ & $\begin{array}{l}8.81 \pm \\
0.15\end{array}$ & $\begin{array}{l}3.23 \pm \\
0.13^{b}\end{array}$ & $\begin{array}{l}0.77 \pm \\
0.02\end{array}$ \\
\hline $75 \mathrm{IU}$ & 36 & $\begin{array}{l}3.34 \pm \\
0.17^{b}\end{array}$ & $\begin{array}{l}4.50 \pm \\
0.05^{b}\end{array}$ & $\begin{array}{l}3.91 \pm \\
0.14\end{array}$ & $\begin{array}{l}0.20 \pm \\
0.01^{\mathrm{a}}\end{array}$ & $\begin{array}{l}87.31 \pm \\
0.19^{a b}\end{array}$ & $\begin{array}{l}12.69 \\
\pm \\
0.19^{a b}\end{array}$ & $\begin{array}{l}8.78 \pm \\
0.18\end{array}$ & $\begin{array}{l}3.28 \pm \\
0.11^{\mathrm{ab}}\end{array}$ & $\begin{array}{l}0.77 \pm \\
0.02\end{array}$ \\
\hline 150 IU & 36 & $\begin{array}{l}3.66 \pm \\
0.14^{\mathrm{a}}\end{array}$ & $\begin{array}{l}4.46 \pm \\
0.06^{b}\end{array}$ & $\begin{array}{l}3.96 \pm \\
0.14\end{array}$ & $\begin{array}{l}0.20 \pm \\
0.01^{\mathrm{a}}\end{array}$ & $\begin{array}{l}87.00 \pm \\
0.16^{\mathrm{b}}\end{array}$ & $\begin{array}{l}13.00 \\
\pm \\
0.16^{a}\end{array}$ & $\begin{array}{l}9.04 \pm \\
0.17\end{array}$ & $\begin{array}{l}3.52 \pm \\
0.11^{a}\end{array}$ & $\begin{array}{l}0.78 \pm \\
0.01\end{array}$ \\
\hline P. value & & 0.0372 & 0.0023 & 0.1511 & 0.0238 & 0.0302 & 0.0302 & 0.1652 & 0.0463 & 0.6247 \\
\hline \multicolumn{11}{|l|}{$\begin{array}{l}\text { Stage of } \\
\text { Lactation }\end{array}$} \\
\hline $\begin{array}{l}\text { Early ( } 1^{\text {st }} \\
\left.-4^{\text {th }} w k\right)\end{array}$ & 36 & $\begin{array}{l}3.00 \pm \\
0.12^{c}\end{array}$ & $\begin{array}{l}4.55 \pm \\
0.05^{a}\end{array}$ & $\begin{array}{l}3.82 \pm \\
0.13\end{array}$ & $\begin{array}{l}0.19 \pm \\
0.01\end{array}$ & $\begin{array}{l}87.74 \pm \\
0.15^{a}\end{array}$ & $\begin{array}{l}12.26 \\
\pm \\
0.15^{\mathrm{c}}\end{array}$ & $\begin{array}{l}8.44 \pm \\
0.12^{c}\end{array}$ & $\begin{array}{l}2.84 \pm \\
0.11^{b}\end{array}$ & $\begin{array}{l}0.77 \pm \\
0.02\end{array}$ \\
\hline $\begin{array}{l}\text { Mid (5th } \\
-8^{\text {th }} \text { wk) }\end{array}$ & 36 & $\begin{array}{l}3.44 \pm \\
0.15^{b}\end{array}$ & $\begin{array}{l}4.44 \pm \\
0.05^{\mathrm{b}}\end{array}$ & $\begin{array}{l}4.02 \pm \\
0.16\end{array}$ & $\begin{array}{l}0.19 \pm \\
0.01\end{array}$ & $\begin{array}{l}87.20 \pm \\
0.18^{b}\end{array}$ & $\begin{array}{l}12.80 \\
\pm \\
0.18^{b}\end{array}$ & $\begin{array}{l}8.78 \pm \\
0.18^{b}\end{array}$ & $\begin{array}{l}3.31 \pm \\
0.11^{\mathrm{a}}\end{array}$ & $\begin{array}{l}0.78 \pm \\
0.01\end{array}$ \\
\hline $\begin{array}{l}\text { Late }\left(9^{\text {th }}\right. \\
\left.-12^{\text {th }} w k\right)\end{array}$ & 36 & $\begin{array}{l}3.88 \pm \\
0.15^{a}\end{array}$ & $\begin{array}{l}4.62 \pm \\
0.05^{a}\end{array}$ & $\begin{array}{l}3.76 \pm \\
0.10\end{array}$ & $\begin{array}{l}0.21 \pm \\
0.01\end{array}$ & $\begin{array}{l}86.83 \pm \\
0.15^{c}\end{array}$ & $\begin{array}{l}13.17 \\
\pm \\
0.15^{a}\end{array}$ & $\begin{array}{l}9.41 \pm \\
0.15^{a}\end{array}$ & $\begin{array}{l}3.53 \pm \\
0.11^{\mathrm{a}}\end{array}$ & $\begin{array}{l}0.77 \pm \\
0.03\end{array}$ \\
\hline P.value & & 0.0001 & 0.0046 & 0.0783 & 0.0559 & 0.0001 & 0.0001 & 0.0001 & 0.0003 & 0.2213 \\
\hline \multicolumn{11}{|l|}{$\begin{array}{l}\text { Storage } \\
\text { duration } \\
\left(w k,-4^{0} \mathrm{C}\right)\end{array}$} \\
\hline 1 & 9 & $\begin{array}{l}3.46 \pm \\
0.19^{\text {bcde }}\end{array}$ & $\begin{array}{l}4.25 \pm \\
0.13^{d}\end{array}$ & $\begin{array}{l}5.20 \pm \\
0.20^{\mathrm{a}}\end{array}$ & $\begin{array}{l}0.20 \pm \\
0.02\end{array}$ & $\begin{array}{l}86.33 \pm \\
0.34^{c}\end{array}$ & $\begin{array}{l}13.67 \\
\pm \\
0.34^{a}\end{array}$ & $\begin{array}{l}8.48 \pm \\
0.26^{\mathrm{cd}}\end{array}$ & $\begin{array}{l}3 \quad 3.37 \\
\pm \\
0.19^{a b c}\end{array}$ & $\begin{array}{l}0.77 \pm \\
0.01\end{array}$ \\
\hline 2 & 9 & $\begin{array}{l}3.00 \pm \\
0.15^{\text {de }}\end{array}$ & $\begin{array}{l}4.62 \pm \\
0.10^{a b}\end{array}$ & $\begin{array}{l}4.44 \pm \\
0.24^{b}\end{array}$ & $\begin{array}{l}0.21 \pm \\
0.01\end{array}$ & $\begin{array}{l}87.18 \pm \\
0.15^{b}\end{array}$ & $\begin{array}{l}12.82 \\
\pm \\
0.15^{b}\end{array}$ & $\begin{array}{l}8.39 \pm \\
0.20^{\text {cd }}\end{array}$ & $\begin{array}{l}3.13 \pm \\
0.12^{\mathrm{bc}}\end{array}$ & $\begin{array}{l}0.77 \pm \\
0.01\end{array}$ \\
\hline 3 & 9 & $\begin{array}{l}3.76 \pm \\
0.32^{\mathrm{ab}}\end{array}$ & $\begin{array}{l}4.38 \pm \\
0.13^{b c}\end{array}$ & $\begin{array}{l}4.21 \pm \\
0.21^{\mathrm{bc}}\end{array}$ & $\begin{array}{l}0.22 \pm \\
0.02\end{array}$ & $\begin{array}{l}86.81 \pm \\
0.32^{b c}\end{array}$ & $\begin{array}{l}13.19 \\
\pm \\
0.32^{\mathrm{ab}}\end{array}$ & $\begin{array}{l}8.97 \pm \\
0.21^{\mathrm{bc}}\end{array}$ & $\begin{array}{l}3.80 \pm \\
0.23^{\mathrm{a}}\end{array}$ & $\begin{array}{l}0.76 \pm \\
0.03\end{array}$ \\
\hline 4 & 9 & $\begin{array}{l}3.08 \pm \\
0.19^{\text {cde }}\end{array}$ & $\begin{array}{l}4.50 \pm \\
0.11^{b c}\end{array}$ & $\begin{array}{l}4.52 \pm \\
0.21^{b}\end{array}$ & $\begin{array}{l}0.18 \pm \\
0.02\end{array}$ & $\begin{array}{l}87.12 \pm \\
0.21^{b}\end{array}$ & $\begin{array}{l}12.88 \\
\pm \\
0.21^{b}\end{array}$ & $\begin{array}{l}8.36 \pm \\
0.20^{\text {cd }}\end{array}$ & $\begin{array}{l}3.19 \pm \\
0.15^{\mathrm{bc}}\end{array}$ & $\begin{array}{l}0.78 \pm \\
0.02\end{array}$ \\
\hline 5 & 9 & $\begin{array}{l}2.85 \pm \\
0.12^{\mathrm{e}}\end{array}$ & $\begin{array}{l}4.51 \pm \\
0.09 \mathrm{bc}\end{array}$ & $\begin{array}{l}4.28 \pm \\
0.19^{b}\end{array}$ & $\begin{array}{l}0.19 \pm \\
0.01\end{array}$ & $\begin{array}{l}87.56 \pm \\
0.19^{a b}\end{array}$ & $\begin{array}{l}12.44 \\
\pm \\
0.19^{\mathrm{bc}}\end{array}$ & $\begin{array}{l}8.16 \pm \\
0.17^{d}\end{array}$ & $\begin{array}{l}3.01 \pm \\
0.10^{c}\end{array}$ & $\begin{array}{l}0.80 \pm \\
0.02\end{array}$ \\
\hline
\end{tabular}




\begin{tabular}{|c|c|c|c|c|c|c|c|c|c|c|}
\hline 6 & 9 & $\begin{array}{l}3.19 \pm \\
0.19^{\text {bcde }}\end{array}$ & $\begin{array}{l}4.49 \pm \\
0.09^{b c}\end{array}$ & $\begin{array}{l}3.45 \pm \\
0.23^{\mathrm{de}}\end{array}$ & $\begin{array}{l}0.18 \pm \\
0.01\end{array}$ & $\begin{array}{l}88.08 \pm \\
0.27^{\mathrm{a}}\end{array}$ & $\begin{array}{l}11.92 \\
\pm \\
0.27^{c}\end{array}$ & $\begin{array}{l}8.47 \pm \\
0.17^{c d}\end{array}$ & $\begin{array}{l}3.28 \pm \\
0.16^{\mathrm{abc}}\end{array}$ & $\begin{array}{l}0.79 \\
\pm 0.02\end{array}$ \\
\hline 7 & 9 & $\begin{array}{l}3.53 \pm \\
0.43^{\mathrm{abcd}}\end{array}$ & $\begin{array}{l}4.39 \pm \\
0.10^{\text {cd }}\end{array}$ & $\begin{array}{l}3.76 \pm \\
0.16^{\mathrm{cd}}\end{array}$ & $\begin{array}{l}0.18 \pm \\
0.02\end{array}$ & $\begin{array}{l}87.56 \pm \\
0.44^{\mathrm{ab}}\end{array}$ & $\begin{array}{l}12.44 \\
\pm \\
0.44^{\mathrm{bc}}\end{array}$ & $\begin{array}{l}8.68 \pm \\
0.40^{\mathrm{bcd}}\end{array}$ & $\begin{array}{l}3.40 \pm \\
0.40^{\mathrm{abc}}\end{array}$ & $\begin{array}{l}0.76 \pm \\
0.05\end{array}$ \\
\hline 8 & 9 & $\begin{array}{l}3.80 \pm \\
0.31^{\mathrm{ab}}\end{array}$ & $\begin{array}{l}4.60 \pm \\
0.09^{\mathrm{abc}}\end{array}$ & $\begin{array}{l}3.37 \pm \\
0.18^{\mathrm{de}}\end{array}$ & $\begin{array}{l}0.20 \pm \\
0.02\end{array}$ & $\begin{array}{l}87.46 \pm \\
0.33^{\mathrm{ab}}\end{array}$ & $\begin{array}{l}12.54 \\
\pm \\
0.33^{b c}\end{array}$ & $\begin{array}{l}9.17 \pm \\
0.32^{\mathrm{ab}}\end{array}$ & $\begin{array}{l}3.77 \pm \\
0.25^{\mathrm{a}}\end{array}$ & $\begin{array}{l}0.78 \pm \\
0.01\end{array}$ \\
\hline 9 & 9 & $\begin{array}{l}3.46 \pm \\
0.45^{\text {bcde }}\end{array}$ & $\begin{array}{l}4.64 \pm \\
0.10^{\mathrm{ab}}\end{array}$ & $\begin{array}{l}3.20 \pm \\
0.10^{\mathrm{e}}\end{array}$ & $\begin{array}{l}0.18 \pm \\
0.01\end{array}$ & $\begin{array}{l}87.93 \pm \\
0.51^{\mathrm{a}}\end{array}$ & $\begin{array}{l}12.07 \\
\pm \\
0.51^{\mathrm{C}}\end{array}$ & $\begin{array}{l}8.87 \pm \\
0.45^{b c}\end{array}$ & $\begin{array}{l}3.01 \pm \\
0.17^{c}\end{array}$ & $\begin{array}{l}0.77 \pm \\
0.05\end{array}$ \\
\hline 10 & 9 & $\begin{array}{l}4.10 \pm \\
0.32^{\mathrm{a}}\end{array}$ & $\begin{array}{l}4.77 \pm \\
0.08^{\mathrm{a}}\end{array}$ & $\begin{array}{l}3.34 \pm \\
0.06^{\mathrm{de}}\end{array}$ & $\begin{array}{l}0.20 \pm \\
0.02\end{array}$ & $\begin{array}{l}87.02 \pm \\
0.30^{\mathrm{bc}}\end{array}$ & $\begin{array}{l}12.98 \\
\pm \\
0.30^{\mathrm{ab}}\end{array}$ & $\begin{array}{l}9.64 \pm \\
0.33^{\mathrm{a}}\end{array}$ & $\begin{array}{l}3.65 \pm \\
0.28^{\mathrm{ab}}\end{array}$ & $\begin{array}{l}0.77 \pm \\
0.03\end{array}$ \\
\hline 11 & 9 & $\begin{array}{l}3.68 \pm \\
0.36^{\mathrm{abc}}\end{array}$ & $\begin{array}{l}4.67 \pm \\
0.07^{\mathrm{ab}}\end{array}$ & $\begin{array}{l}3.43 \pm \\
0.10^{\mathrm{de}}\end{array}$ & $\begin{array}{l}0.19 \pm \\
0.01\end{array}$ & $\begin{array}{l}86.87 \pm \\
0.32^{\mathrm{bc}}\end{array}$ & $\begin{array}{l}13.13 \\
\pm \\
0.32^{\mathrm{ab}}\end{array}$ & $\begin{array}{l}9.70 \pm \\
0.36^{\mathrm{a}}\end{array}$ & $\begin{array}{l}3.65 \pm \\
0.28^{\mathrm{bc}}\end{array}$ & $\begin{array}{l}0.77 \pm \\
0.04\end{array}$ \\
\hline 12 & 9 & $\begin{array}{l}3.38 \pm \\
0.28^{\text {bcde }}\end{array}$ & $\begin{array}{l}4.62 \pm \\
0.11^{\mathrm{ab}}\end{array}$ & $\begin{array}{l}3.25 \pm \\
0.05^{\mathrm{de}}\end{array}$ & $\begin{array}{l}0.23 \pm \\
0.01\end{array}$ & $\begin{array}{l}87.11 \pm \\
0.29^{b}\end{array}$ & $\begin{array}{l}12.89 \\
\pm \\
0.29^{b}\end{array}$ & $\begin{array}{l}9.64 \pm \\
0.29^{\mathrm{a}}\end{array}$ & $\begin{array}{l}3.36 \pm \\
0.17^{\mathrm{abc}}\end{array}$ & $\begin{array}{l}0.78 \pm \\
0.05\end{array}$ \\
\hline P. value & & 0.0017 & 0.0002 & 0.0001 & 0.0993 & 0.0002 & 0.0002 & 0.0001 & 0.0095 & 0.3145 \\
\hline
\end{tabular}




\begin{tabular}{|c|c|c|c|c|c|c|}
\hline Factors & $\mathrm{N}$ & $\begin{array}{l}\text { Calcium } \\
\text { (mg/100g) }\end{array}$ & $\begin{array}{l}\text { Phosphorous } \\
\text { (mg/100g) }\end{array}$ & $\begin{array}{l}\text { Sodium } \\
(\mathrm{mg} / 100 \mathrm{~g})\end{array}$ & $\begin{array}{c}\text { Zinc } \\
(\mathrm{mg} / 100 \mathrm{~g})\end{array}$ & $\begin{array}{c}\text { Copper } \\
\text { (mg/100g) }\end{array}$ \\
\hline \multicolumn{7}{|l|}{ Vitamin E } \\
\hline OIU & 48 & $275.53 \pm 14.95^{a}$ & $30.22 \pm 2.40^{\mathrm{a}}$ & $59.17 \pm 5.28$ & $2.27 \pm 0.15$ & $0.18 \pm 0.02$ \\
\hline $75 I U$ & 48 & $183.57 \pm 12.11^{\mathrm{b}}$ & $23.27 \pm 2.13^{b}$ & $48.94 \pm 1.45$ & $2.14 \pm 0.14$ & $0.15 \pm 0.01$ \\
\hline $150 I U$ & 48 & $257.63 \pm 8.22^{\mathrm{a}}$ & $22.13 \pm 1.39^{b}$ & $50.87 \pm 0.48$ & $2.24 \pm 0.09$ & $0.17 \pm 0.02$ \\
\hline P. Value & & 0.0001 & 0.0088 & 0.0572 & 0.6688 & 0.1855 \\
\hline \multicolumn{7}{|c|}{$\begin{array}{l}\text { Stage of lactation } \\
(\mathrm{wk})\end{array}$} \\
\hline Early $\left(1 \mathrm{st}-4^{\text {th }}\right)$ & 48 & $266.21 \pm 9.23^{a}$ & $28.98 \pm 2.53^{\mathrm{a}}$ & $52.94 \pm 0.74$ & $\begin{array}{l}2.68 \pm \\
0.12^{\mathrm{a}}\end{array}$ & $0.22 \pm 0.02^{\mathrm{a}}$ \\
\hline Mid $\left(5\right.$ th $\left.-8^{\text {th }}\right)$ & 48 & $250.56 \pm 17.05^{a}$ & $25.73 \pm 1.92^{\mathrm{ab}}$ & $57.87 \pm 5.32$ & $\begin{array}{l}2.36 \pm \\
0.14^{\mathrm{b}}\end{array}$ & $0.18 \pm 0.02^{\mathrm{a}}$ \\
\hline Late $\left(9\right.$ th $\left.-12^{\text {th }}\right)$ & 48 & $199.95 \pm 10.59^{b}$ & $20.91 \pm 1.50^{b}$ & $48.16 \pm 1.26$ & $\begin{array}{l}1.59 \pm \\
0.06^{\mathrm{c}}\end{array}$ & $0.10 \pm 0.01^{b}$ \\
\hline P. Value & & 0.0001 & 0.0224 & 0.0595 & 0.0001 & 0.0001 \\
\hline \multicolumn{7}{|c|}{ Storage duration (wk) } \\
\hline 1 & 12 & $226.98 \pm 20.83$ & $28.60 \pm 4.45$ & $51.10 \pm 1.14$ & $2.02 \pm 0.16$ & $0.15 \pm 0.04^{\mathrm{bcd}}$ \\
\hline 2 & 12 & $224.00 \pm 18.46$ & $21.67 \pm 2.88$ & $50.34 \pm 0.94$ & $1.95 \pm 0.11$ & $0.11 \pm 0.02^{\mathrm{cd}}$ \\
\hline 3 & 12 & $231.58 \pm 19.79$ & $26.15 \pm 3.22$ & $53.43 \pm 2.38$ & $2.26 \pm 0.26$ & $0.10 \pm 0.03^{d}$ \\
\hline 4 & 12 & $244.23 \pm 20.00$ & $24.61 \pm 3.12$ & $51.17 \pm 1.01$ & $2.21 \pm 0.23$ & $0.14 \pm 0.03^{\mathrm{bcd}}$ \\
\hline 5 & 12 & $225.63 \pm 24.10$ & $28.03 \pm 5.11$ & $49.91 \pm 1.68$ & $2.51 \pm 0.31$ & $\begin{array}{l}0.17 \pm \\
0.04^{\mathrm{abcd}}\end{array}$ \\
\hline 6 & 12 & $270.22 \pm 29.88$ & $30.83 \pm 5.85$ & $58.39 \pm 7.94$ & $2.73 \pm 0.47$ & $\begin{array}{l}0.17 \pm \\
0.04^{\mathrm{abcd}}\end{array}$ \\
\hline 7 & 12 & $234.16 \pm 22.55$ & $25.05 \pm 4.35$ & $50.91 \pm 1.64$ & $2.46 \pm 0.28$ & $\begin{array}{l}0.18 \pm \\
0.04^{\mathrm{abcd}}\end{array}$ \\
\hline 8 & 12 & $213.86 \pm 21.40$ & $24.71 \pm 4.68$ & $49.92 \pm 1.78$ & $2.17 \pm 0.25$ & $0.13 \pm 0.02^{b c d}$ \\
\hline 9 & 12 & $263.44 \pm 56.51$ & $18.12 \pm 4.77$ & $66.75 \pm 20.71$ & $2.01 \pm 0.27$ & $0.22 \pm 0.03^{a b}$ \\
\hline 10 & 12 & $239.86 \pm 27.32$ & $31.06 \pm 4.13$ & $51.96 \pm 1.06$ & $2.15 \pm 0.21$ & $0.20 \pm 0.04^{\mathrm{abc}}$ \\
\hline 11 & 12 & $239.92 \pm 20.00$ & $23.59 \pm 3.74$ & $51.24 \pm 0.83$ & $2.04 \pm 0.19$ & $0.22 \pm 0.04^{\mathrm{ab}}$ \\
\hline 12 & 12 & $253.04 \pm 23.58$ & $20.10 \pm 1.80$ & $50.80 \pm 1.27$ & $2.05 \pm 0.17$ & $0.25 \pm 0.04^{\mathrm{a}}$ \\
\hline P. Value & & 0.5679 & 0.4662 & 0.7409 & 0.2664 & 0.0002 \\
\hline
\end{tabular}


Page 14/14 